\title{
Type 1 Diabetes: Current Perspectives
}

\author{
Aizhan Kozhakhmetova and Kathleen M. Gillespie
}

\begin{abstract}
Type 1 diabetes, resulting from the autoimmune destruction of insulin producing islet beta cells is caused by genetic and environmental determinants. Recent studies agree that counterintuitively, the major genetic susceptibility factors are decreasing in frequency as the incidence of the condition increases. This suggests a growing role for environmental determinants but these have been difficult to identify and our understanding of gene/environment effects are limited. Individuals "at risk" can be identified accurately through the presence of multiple islet autoantibodies and current efforts in type 1 diabetes research focus on improved biomarkers and strategies to prevent or reverse the condition through immunotherapy.
\end{abstract}

Keywords: Type 1 diabetes, Autoimmunity, Insulin, Islet autoantibodies, Genes

\section{Introduction}

Type 1 diabetes (T1D) represents approximately $10 \%$ of diabetes overall and results from the autoimmune destruction of insulin producing beta cells in the islets of Langerhans [1]. The condition is usually diagnosed on clinical grounds and symptoms appear when approximately $70-80 \%$ of pancreatic islets are destroyed [2]. Individuals with T1D cannot survive without insulin replacement and, even when treated with insulin, remain at risk of complications including nephropathy, retinopathy, and coronary heart disease.

Although commonly associated with onset in childhood and adolescence, with a peak age at diagnosis of 12 years, approximately half of all cases of TID are diagnosed in adulthood [3]. Epidemiological studies show that the incidence of TID is unequally distributed in the world's population, with a high incidence rate in Caucasians $(40 / 100,000 /$ year in Finland) and a relatively low rate among Asian and South American populations (0.1/100,000/ year) [4]. The incidence of the condition has been increasing rapidly in recent decades for unknown reasons: the current rate of increase is $3 \%$ per year worldwide [5]. If present trends continue, doubling of new cases of type 1 diabetes in European children younger than 5 years is predicted between 2005 and 2020, and prevalent cases younger than 15 years will rise by $70 \%$ [6]. 


\section{Genetic Susceptibility to Type 1 Diabetes}

The genetic background of TID is very complex influenced by combinations of genes and environmental determinants. Identical twins with evidence of autoimmunity studied over a long follow-up period were concordant in over $50 \%$ indicating that the etiology of the condition is approximately half genetic and half environmental [7]. The life-long risk of developing the disease in a child born in a family with TID is estimated as $20 \%, 8 \%, 5 \%$, or $3 \%$, if the child has two affected first-degree relatives, an affected sibling, father, or mother, respectively [8]. The younger the individual is at diagnosis, the greater the risk to siblings $[9,10]$.

The importance of the Human Leucocyte Antigen (HLA) region ( $8 \mathrm{Mb}$ of chromosome $6 \mathrm{p} 2 \mathrm{l}$ ), in susceptibility to type 1 diabetes has been known since the 1970s [3]. The HLA has multiple roles in $\mathrm{T}$ cell selection, antigen presentation and immune responses, all of which can influence the onset and progression of TID. The HLA region generally can be split into three different parts, class I, class II, and class III (Figs. I and 2).

\section{Chromosome 6}

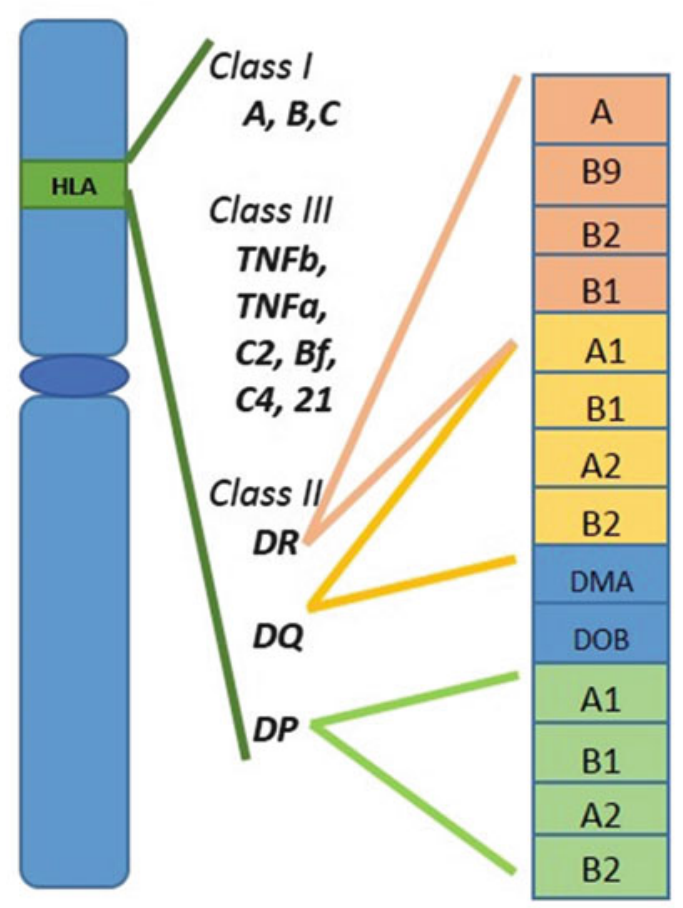

Fig. 1 MHC region of chromosome 6. MHC region is comprised of 3 loci corresponding to HLA Class I, II and III. In HLA Class II region DR, DQ and DP loci are presented. Risk alleles for T1D are located in DR and DQ regions 


\section{MHC Class II}

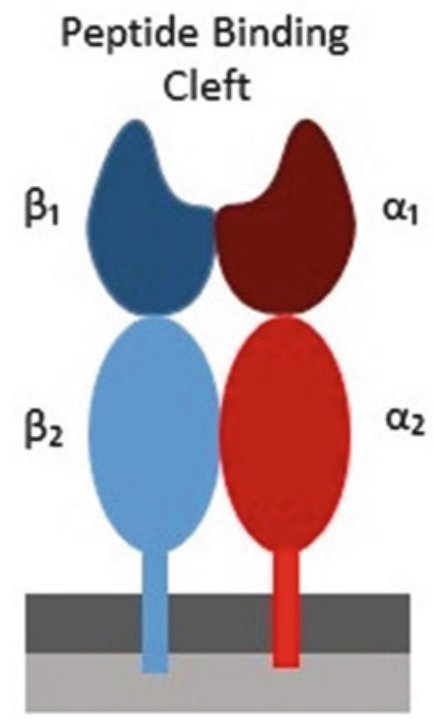

Fig. 2 MHC class II. MHC class II molecules are heterodimeric and consist of two peptides $-\alpha$ and $\beta$ chains, which include $\alpha 1, \beta 1$ domains encoding binding cleft, and $\alpha 2, \beta 2$-membrane bound domain

The class I region, encoding HLA A, B, and C molecules, is expressed on the cell surface of nucleated cells that are involved in the presentation of endogenous antigens to CD8+ cytotoxic T cells (Tc) and contribute to risk of TID [11] and the HLA A* 24 allele is associated with rapid progression to TID [12].

The HLA class II region encodes membrane bound proteins expressed on the cell surface of antigen-presenting cells (APCs): Blymphocytes, macrophages, and dendritic cells that are involved in the processing and presentation of exogenous antigens to CD4+ T helper cells (Th) (Fig. 3) leading to T cell activation. The numerous subsets of T cells are derived from a single $\mathrm{T}$ cell precursor and some subsets have the capacity to regulate one another (Fig. 4).

Studies of the pathogenesis of type 1 diabetes proving roles for the HLA as well as effector and regulator T cell population mechanistically have utilized the predominant animal model of type 1 diabetes, the nonobese diabetic (NOD) mouse transgenic for HLA Class II [13].

HLA class II genes contribute to both susceptibility and resistance to TID; risk is associated with the HLA class II haplotypes $D R B 1^{*} 04-D Q B 1^{*} 0302$ and $D R B 1^{*} 03-D Q B 1^{*} 02$ while the haplotype $D R B 1^{*} 15-D Q B 1^{*} 0602$ is dominantly protective. The risk of 


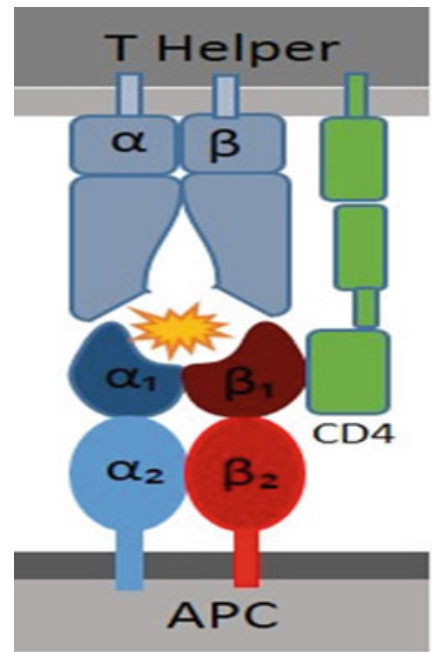

Fig. 3 Antigen presentation. During antigen presentation CD4 receptors of $T$ helper lymphocytes bind to $\beta$ domain of the HLA Class II molecule that activates the T cell

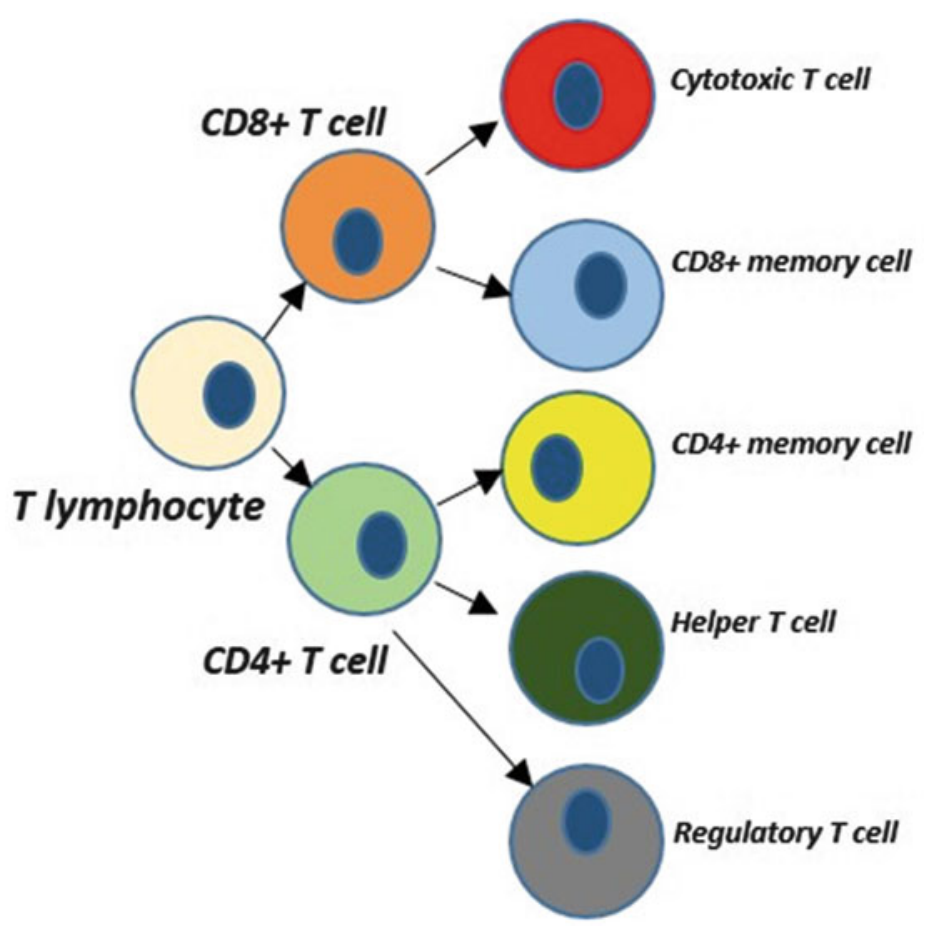

Fig. $4 \mathrm{~T}$ cell subsets. CD8+ T cells mature into cytotoxic T cells, CD8+ memory cells; CD4+ T cells mature into helper T cells, regulatory T cells, CD4+ memory cells 


\section{Selected T1D associated genes}



Fig. 5 The relative effects of selected T1D associated genes on susceptibility to T1D (adapted from Todd, 2010) [15]

developing T1D in siblings of affected children varies from 0.3 to $30 \%$ depending on their HLA class II genotype [14].

Additional genetic risk markers were identified in the $1980 \mathrm{~s}$ and 1990s but the advent of genome-wide association studies (GWAS), conducted since 2007, has allowed identification of approximately 40 additional genes that contribute to susceptibility to TID (Fig. 5) [15]. Ongoing research now focuses on the biological pathways in immune and beta cells where these TID associated genes function [16]. Despite these huge advances, all the genes identified to date do not account for the sum of genetic susceptibility. The concept of "missing heritability" has led to a focus on rare variants.

The increasing role of a "diabetogenic" environment was suggested following reports of the rising incidence and decreasing age at diagnosis of TID while the frequency of the high risk HLA DR3/DR4 genotype is decreasing [17, 18]. A variety of environmental factors such as infections in early life, diet, and early development of the gut microbiome have been implicated in promoting the rising incidence of TID [19] but none yet unequivocally proven. It is likely that one mechanism by which the environment influences risk of autoimmune diabetes is through epigenetic changes. 


\section{The Natural History of Type 1 Diabetes}

Over the last 20 years, a series of birth cohort studies [20-23] have contributed hugely to our understanding of the natural history of the condition. Islet antibodies are markers of ongoing autoimmune destruction [24] and the best characterized are specific to the islet proteins insulin [25], glutamic acid decarboxylase (GAD) [26], IA2 [27], and the zinc transporter ZnT8 [28, 29]. The autoimmune process begins very early in life: studies of neonatal diabetes suggest that most cases of diabetes diagnosed before 6 months are unlikely to be autoimmune, but those diagnosed after the age of 6 months have the genetic characteristics of TID [30]. Antibodies to insulin (generally the first to appear) have been detected as early as 6-12 months of age [31]. Longer term follow-up of birth cohorts in Finland and Germany suggests that there is an explosion of islet autoimmunity in at risk children between the ages of 6 months and 3 years [21, 32]. The techniques to detect islet autoantibodies with high sensitivity and specificity have resulted from decades of collaborative workshops where blinded reference samples are tested in participating laboratories [33] resulting in high quality radioimmunoassays [34] and more recently ELISAs and chemiluminescence assays [35].

Islet autoantibody studies have demonstrated differing rates of progression in individuals positive for multiple islet autoantibodies; many progress rapidly [27] but there is also accumulating evidence for "slow burning" autoimmunity. For instance, within the Bart's Oxford study of type l diabetes (http://www.bristol.ac.uk/clinicalsciences/research/diabetes/research/box/), ongoing since 1985, some "at risk" individuals with two or more islet autoantibodies remain diabetes free after 20 years. A relapsing/remitting process of beta cell destruction has been postulated that could help explain differences in rates of progression but as yet there is no widely available marker of beta cell death although an assay to detect demethylated insulin for this purpose has been described [36, 37].

Although the pancreas in type 1 diabetes has been described previously $[38,39]$, recent histological analysis revealed new insights into the immune cell subsets comprising insulitis with the observation that $\mathrm{B}$ cells are present in greater frequency than expected [40]. Further analysis of TID pancreas has been made possible by the Network for pancreatic organ donors with diabetes (nPOD) initiative (www.jdrfnpod.org). Improving techniques raise the possibility of analysis of single laser captured islet beta cells.

Once diagnosed, the insulin-free "honeymoon period" is variable and there is increasing evidence that some individuals with long-standing diabetes can continue to make low levels of insulin [41]. Large scale testing has been made possible through a straightforward test to detect c-peptide in urine [42]. 
Future perspectives in type 1 diabetes include improved biomarker identification to support a number of ongoing clinical trials orchestrated internationally by the TrialNet consortium (www. diabetestrialnet.org).

\section{References}

1. Tisch R, Devitt H (1996) Insulin-dependent diabetes mellitus. Cell 85:291-297

2. Butler AE, Galasso R, Meier JJ, Basu R, Rizza RA, Butler PC (2007) Modestly increased beta cell apoptosis but no increased beta cell replication in recent-onset type 1 diabetic patients who died of diabetic ketoacidosis. Diabetologia 50:2323-2331

3. Gillespie K. (2011) The genetics of type 1 diabetes, type 1 diabetes - pathogenesis, genetics and immunotherapy, Prof. David Wagner (Ed.), ISBN: 978-953-307-362-0, Rijeka, Croatia: InTech, Available from: http://www. intechopen.com/books/type-1-diabetes-path ogenesis-genetics-and-immunotherapy/thegeneticsof-type-1-diabetes

4. Karvonen M, Viik-Kajander M, Moltchanova E, Libman I, LaPorte R, Tuomilehto J (2000) Incidence of childhood type 1 diabetes worldwide. Diabetes Mondiale (DiaMond) Project Group. Diabetes Care 23:1516-1526

5. Onkamo P, Vaananen S, Karvonen M, Tuomilehto J (1999) Worldwide increase in incidence of type 1 diabetes - the analysis of the data on published incidence trends. Diabetologia 42:1395-1403

6. Patterson CC, Dahlquist GG, Gyurus E, Green A, Soltesz G (2009) Incidence trends for childhood type 1 diabetes in Europe during 19892003 and predicted new cases 2005-20: a multicentre prospective registration study. Lancet 373:2027-2033

7. Redondo MJ, Yu L, Hawa M, Mackenzie T, Pyke DA, Eisenbarth GS et al (2001) Heterogeneity of type I diabetes: analysis of monozygotic twins in Great Britain and the United States. Diabetologia 44:354-362

8. Schenker M, Hummel M, Ferber K, Walter M, Keller E, Albert ED et al (1999) Early expression and high prevalence of islet autoantibodies for DR3/4 heterozygous and DR4/4 homozygous offspring of parents with Type I diabetes: the German BABYDIAB study. Diabetologia 42:671-677

9. Gillespie KM, Gale EA, Bingley PJ (2002) High familial risk and genetic susceptibility in early onset childhood diabetes. Diabetes 51:210-214
10. Gillespie KM, Aitken RJ, Wilson I, Williams AJ, Bingley PJ (2014) Early onset of diabetes in the proband is the major determinant of risk in HLA DR3-DQ2/DR4-DQ8 siblings. Diabetes 63:1041-1047

11. Nejentsev S, Howson JM, Walker NM, Szeszko J, Field SF, Stevens HE et al (2007) Localization of type 1 diabetes susceptibility to the MHC class I genes HLA-B and HLA-A. Nature 450:887-892

12. Mbunwe E, Van der Auwera BJ, Vermeulen I, Demeester S, Van Dalem A, Balti EV et al (2013) HLA-A*24 is an independent predictor of 5-year progression to diabetes in autoantibody-positive first-degree relatives of type 1 diabetic patients. Diabetes 62:1345-1350

13. Mellanby RJ, Phillips JM, Parish NM, Cooke A (2008) Both central and peripheral tolerance mechanisms play roles in diabetes prevention in NOD-E transgenic mice. Autoimmunity 41:383-394

14. Lambert AP, Gillespie KM, Thomson G, Cordell HJ, Todd JA, Gale EAM et al (2004) Absolute risk of childhood-onset type 1 diabetes defined by human leukocyte antigen class II genotype: a population-based study in the United Kingdom. J Clin Endocrinol Metab 89:4037-4043

15. Todd JA (2010) Etiology of type 1 diabetes. Immunity 32:457-467

16. Marroqui L, Santin I, Dos Santos RS, Marselli L, Marchetti P, Eizirik DL (2014) BACH2, a candidate risk gene for type 1 diabetes, regulates apoptosis in pancreatic beta-cells via JNKl modulation and crosstalk with the candidate gene PTPN2. Diabetes 63:2516-2527

17. Gillespie KM, Bain SC, Barnett AH, Bingley PJ, Christie MR, Gill GV, Gale EA (2004) The rising incidence of childhood type 1 diabetes and reduced contribution of high-risk HLA haplotypes. Lancet 364:1699-1700

18. Fourlanos S, Varney MD, Tait BD, Morahan G, Honeyman MC, Colman PG et al (2008) The rising incidence of type 1 diabetes is accounted for by cases with lower-risk human leukocyte antigen genotypes. Diabetes Care 31:1546-1549 
19. Knip M, Simell O (2012) Environmental triggers of type 1 diabetes. Cold Spring Harb Perspect Med 2:a007690

20. Hermann R, Turpeinen H, Laine AP, Veijola R, Knip M, Simell O et al (2003) HLA DR-DQencoded genetic determinants of childhoodonset type 1 diabetes in Finland: an analysis of 622 nuclear families. Tissue Antigens 62:162-169

21. Ziegler AG, Rewers M, Simell O, Simell T, Lempainen J, Steck A et al (2013) Seroconversion to multiple islet autoantibodies and risk of progression to diabetes in children. JAMA 309:2473-2479

22. Barker JM, Barriga KJ, Yu L, Miao D, Erlich HA, Norris JM et al (2004) Prediction of Autoantibody positivity and progression to type 1 diabetes: Diabetes Autoimmunity Study in the Young (DAISY). J Clin Endocrinol Metab 89:3896-3902

23. Bingley PJ, Bonifacio E, Williams AJ, Genovese S, Bottazzo GF, Gale EA (1997) Prediction of IDDM in the general population: strategies based on combinations of autoantibody markers. Diabetes 46:1701-1710

24. Bottazzo GF, Dean BM, McNally JM, Mackay EH, Swift PGF, Gamble DR (1985) In situ characterisation of autoimmune phenomena and expression of HLA molecules in the pancreas in diabetic insulitis. $\mathrm{N}$ Engl $\mathrm{J}$ Med 313:353-360

25. Palmer JP, Asplin CM, Clemons P, Lyen K, Tatpati O, Raghu PK et al (1983) Insulin antibodies in insulin-dependent diabetics before insulin treatment. Science 222:1337-1339

26. Baekkeskov S, Bruining GJ, Molenaar L, Sigurdsson E, Christgau S (1989) Predictive value of $\mathrm{Mr} 64,000$ antibodies for Type 1 (insulin-dependent) diabetes in a childhood population. Diabetologia 32:463A

27. Christie MR, Genovese S, Cassidy D, Bosi E, Brown TJ, Lai M et al (1994) Antibodies to islet $37 \mathrm{k}$ antigen but not to glutamate decarboxylase discriminate rapid progression to insulin-dependent diabetes mellitus in endocrine autoimmunity. Diabetologia 43:1254-1259

28. Wenzlau JM, Juhl K, Yu L, Moua O, Sarkar SA, Gottlieb P et al (2007) The cation efflux transporter ZnT8 (Slc30A8) is a major autoantigen in human type 1 diabetes. Proc Natl Acad Sci U S A 104:17040-17045

29. Wenzlau JM, Liu Y, Yu L, Moua O, Fowler KT, Rangasamy $S$ et al (2008) A common nonsynonymous single nucleotide polymorphism in the SLC30A8 gene determines ZnT8 autoantibody specificity in type 1 diabetes. Diabetes 57:2693-2697

30. Edghill EL, Dix RJ, Flanagan SE, Bingley PJ, Hattersley AT, Ellard S et al (2006) HLA genotyping supports a nonautoimmune etiology in patients diagnosed with diabetes under the age of 6 months. Diabetes 55:1895-1898

31. Roll U, Christie MR, Fuchtensbusch M, Payton MA, Hawkes CJ, Ziegler AG (1996) Perinatal autoimmunity in offspring of diabetic parents: the German Multicenter BABY-DIAB Study: detection of humoral immune responses to islet autoantigens in early childhood. Diabetes 145:967-973

32. Parikka V, Nanto-Salonen K, Saarinen M, Simell T, Ilonen J, Hyoty H et al (2012) Early seroconversion and rapidly increasing autoantibody concentrations predict prepubertal manifestation of type 1 diabetes in children at genetic risk. Diabetologia 55:1926-1936

33. Bingley PJ, Williams AJ (2004) Validation of autoantibody assays in type 1 diabetes: workshop programme. Autoimmunity 37:257-260

34. Williams AJ, Bingley PJ, Bonifacio E, Palmer JP, Gale EA (1997) A novel micro-assay for insulin autoantibodies. J Autoimmun 10:473-478

35. Yu L, Dong F, Miao D, Fouts AR, Wenzlau JM, Steck AK (2013) Proinsulin/Insulin autoantibodies measured with electrochemiluminescent assay are the earliest indicator of prediabetic islet autoimmunity. Diabetes Care 36:2266-2270

36. Akirav EM, Lebastchi J, Galvan EM, Henegariu $\mathrm{O}$, Akirav $\mathrm{M}$, Ablamunits $\mathrm{V}$ et al (2011) Detection of $\beta$ cell death in diabetes using differentially methylated circulating DNA. Proc Natl Acad Sci U S A 108:19018-19023

37. Herold KC, Usmani-Brown S, Ghazi T, Lebastchi J, Beam CA, Bellin MD et al (2015) Beta Cell death and dysfunction during type 1 diabetes development in at-risk individuals. J Clin Invest 125:1163-1173

38. Gepts W, DeMey J (1978) Islet cell survival determined by morphology: an immunocytochemical study of the islet of Langerhans in juvenile diabetes mellitus. Diabetes 27:251-261

39. Foulis AK, Liddle CN, Farquharson MA, Richmond JA, Weir RS (1986) The histopathology of the pancreas in Type 1 (insulin-dependent) diabetes mellitus: a 25-year review of deaths in patients under 20 years of age in the United Kingdom. Diabetologia 29:267-274

40. Willcox A, Richardson SJ, Bone AJ, Foulis AK, Morgan NG (2009) Analysis of islet inflammation in human type 1 diabetes. Clin Exp Immunol 155:173-181 
41. Oram RA, Jones AG, Besser RE, Knight BA, Shields BM, Brown RJ et al (2014) The majority of patients with long-duration type 1 diabetes are insulin microsecretors and have functioning beta cells. Diabetologia 57:187-191
42. McDonald TJ, Knight BA, Shields BM, Bowman P, Salzmann MB, Hattersley AT (2009) Stability and reproducibility of a single-sample urinary C-peptide/creatinine ratio and its correlation with 24-h urinary C-peptide. Clin Chem 55:2035-2039 


\section{Author Queries}

Chapter No.: 289

\begin{tabular}{|l|l|l|}
\hline Query Refs. & Details Required & Author's response \\
\hline AU1 & Please check the chapter title for correctness. & \\
\hline
\end{tabular}

